\title{
Role of sediment denitrification in water column oxygen dynamics: comparison of the North American East and West Coasts
}

\author{
L. Bianucci ${ }^{1}$, K. Fennel ${ }^{1}$, and K. L. Denman ${ }^{2}$ \\ ${ }^{1}$ Department of Oceanography, Dalhousie University, Canada \\ ${ }^{2}$ VENUS Project, School of Earth and Ocean Sciences, and Canadian Centre for Climate Modelling and Analysis, \\ University of Victoria, Canada \\ Correspondence to: L. Bianucci (laura.bianucci@dal.ca)
}

Received: 13 December 2011 - Published in Biogeosciences Discuss.: 2 January 2012

Revised: 15 May 2012 - Accepted: 27 June 2012 - Published: 24 July 2012

\begin{abstract}
Low oxygen concentrations, either natural or anthropogenically driven, can severely affect coastal marine ecosystems. A deeper understanding of oxygen dynamics is required in order to improve numerical models, eventually to predict the timing and severity of hypoxia. In this study we investigate the effect of sediment denitrification on oxygen concentrations in bottom waters over the continental shelf. We used two coupled physical-biological models based on the Regional Ocean Modelling System (ROMS) to compare summer simulations with and without denitrification within the sediments for two North American shelves: the Middle Atlantic Bight (MAB) and the Vancouver Island Shelf (VIS). These regions belong to western and eastern boundary current systems, respectively, and are characterized by different physical and biological dynamics. Both models assume coupled nitrification-denitrification within the sediments. Denitrification represents a loss of bioavailable nitrogen through the production of dinitrogen gas, with the potential to affect biogeochemical cycles. In our MAB model, this loss of regenerated nutrients through denitrification within the sediments significantly affects primary production, since recycled nitrogen supports most of the primary production in that region. The diminished primary production and consequent decrease of organic matter flux to the seafloor leads to less sediment oxygen consumption and higher oxygen concentrations in bottom waters. However, changes in regenerated nitrogen on the VIS barely affect primary production due to the efficient supply of new nutrients through wind-driven upwelling during summer and the nutrient-rich coastal current. We recommend that modelling experiments focusing
\end{abstract}

on oxygen dynamics (as well as oxygen budget calculations) should include sediment denitrification in coastal regions where regenerated primary production dominates productivity.

\section{Introduction}

Anaerobic remineralization processes become important where oxygen concentrations are low in the water column and in the sediment layer below the oxygenated upper few millimetres (Jørgensen, 1982). Nitrate $\left(\mathrm{NO}_{3}^{-}\right)$is the first electron acceptor used in place of oxygen in the decomposition of organic matter because its energy yield is the highest after oxygen (Sørensen et al., 1979; Middelburg and Levin, 2009). The remineralization of organic matter using $\mathrm{NO}_{3}^{-}$is known as "denitrification". In contrast to aerobic remineralization, end products of denitrification are dinitrogen gas or nitrous oxide and not readily available to most primary producers (Seitzinger, 1988). Thus, this anaerobic process represents a loss of bioavailable nitrogen from the ecosystem and affects water column processes such as primary production and nitrification, with repercussions for the carbon and oxygen cycles. For instance, recent studies in the Middle Atlantic Bight (MAB) and North Sea suggest that the presence of denitrification within the sediments plays an important role in the uptake of atmospheric carbon dioxide $\left(\mathrm{CO}_{2}\right)$ by the coastal ocean (Fennel et al., 2008; Thomas et al., 2009). A high-resolution model of the MAB shows that the loss of bioavailable nitrogen by sediment denitrification 
decreases primary production, leading to a smaller influx of atmospheric $\mathrm{CO}_{2}$ into the ocean than in simulations where denitrification is ignored (Fennel et al., 2008). Observations in the North Sea suggest that anaerobic degradation of organic matter in the sediments (e.g., denitrification, sulphate reduction) represents the largest source of total alkalinity in shallow areas, which provides a stronger control on $\mathrm{pH}$ and surface partial pressure of $\mathrm{CO}_{2}$ than dissolved inorganic carbon (Thomas et al., 2009).

Many studies have focused on the effect of low oxygen concentrations (i.e., hypoxic conditions) on denitrification within the sediments (e.g., Kemp et al., 1990; Middelburg and Levin, 2009). We investigate here whether sediment denitrification can affect oxygen concentrations in bottom waters over the shelf. Previous studies have shown the important role of sedimentary pathways in bottom-water oxygen dynamics (e.g., Middelburg and Soetaert, 2005; Soetaert and Middelburg, 2009; Reed et al., 2011). The water column processes affected by sediment denitrification have the potential to alter oxygen concentrations in several different ways (Fig. 1). Firstly, a decrease in primary production due to less available nitrogen leads to a smaller flux of organic matter reaching the sediments. Consequently, there is a decrease in remineralization and oxygen consumption by the sediments, contributing to higher oxygen concentrations in bottom waters (Process 1). Secondly, the decreased sediment remineralization also diminishes the source of ammonium $\left(\mathrm{NH}_{4}^{+}\right)$to the water column. Therefore, nitrification (the aerobic oxidation of $\mathrm{NH}_{4}^{+}$to $\mathrm{NO}_{3}^{-}$) decreases in the water column, resulting in less oxygen consumption and a potential to increase oxygen concentrations (Process 2). Lastly, one needs to consider the source of $\mathrm{NO}_{3}^{-}$for the denitrifying bacteria in the sediments. $\mathrm{NO}_{3}^{-}$can be provided by the above water column (direct denitrification) or by nitrification within the sediments (coupled nitrification-denitrification). Where the latter dominates, oxygen is taken from the water column to fuel nitrification in the sediments. Hence, coupled nitrification-denitrification leads to an increased oxygen consumption from the sediments, which can contribute to a decrease in oxygen concentrations (Process 3 ). In contrast, direct denitrification represents an extra sink of fixed nitrogen for the water column, with the potential to further decrease primary production (Process 1). These pathways connecting sediment denitrification and oxygen concentrations in the water column have not been explored in detail. Given the crucial role of oxygen in marine ecosystems and the interest in understanding and predicting coastal hypoxia, we need to identify all the mechanisms that control oxygen concentrations. An improved constraint of key local processes (such as sediment denitrification) will allow for the development of better models for coastal hypoxia, as pointed by Peña et al. (2010).

Here we explore the role of denitrification within the sediments on the oxygen dynamics of bottom waters over two

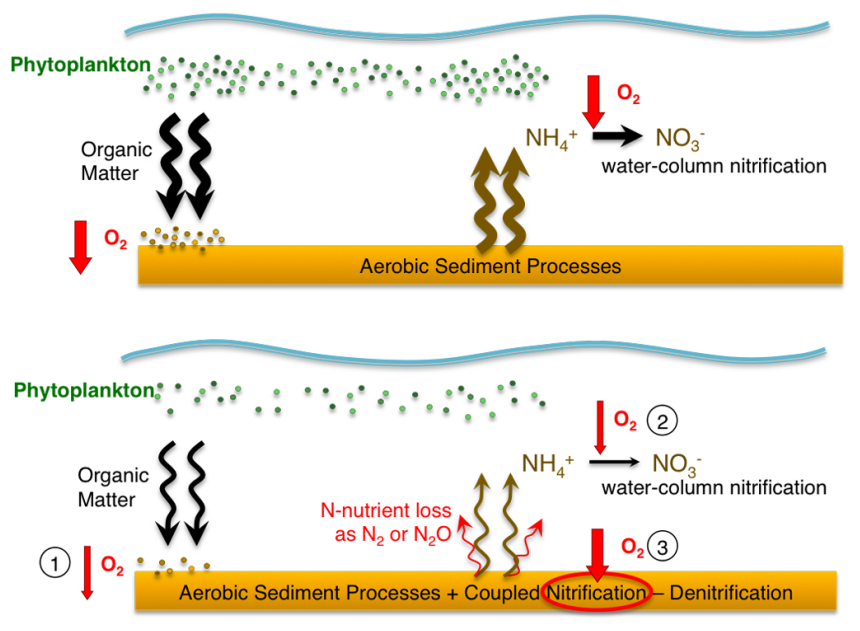

Fig. 1. Schematic of how some ecosystem processes and oxygen consumption are affected by the presence of coupled nitrificationdenitrification in the sediments: top) scenario with only aerobic benthic remineralization; bottom) scenario that also considers coupled nitrification-denitrification within the sediments. The different width of the arrows between panels represents the change in the magnitude of the fluxes in the two scenarios. Numbers in the bottom panel refer to Processes 1, 2, and 3 described in the text.

distinctly different shelves, looking at the broader effects of shelf type and coastal circulation. Two similar coupled biological-physical models, applied to the eastern and western coastal boundary systems of North America, are used to evaluate the role of different environmental settings in the connection between oxygen and sediment denitrification. The two shelves studied are the broad MAB and the narrower Vancouver Island shelf (VIS). Located in the central section of the United States East Coast, the MAB extends from Cape Hatteras in the south to Nantucket Shoals in the north (righthand inset in Fig. 2). A large-scale, coastal current system originating in the Labrador Sea brings cool and relatively fresh waters onto the Scotian Shelf (Chapman and Beardsley, 1989). In the Gulf of Maine, these waters mix with the warmer, more saline slope water, forming the shelf water that predominates in the MAB (Smith, 1983; Ramp et al., 1985). Shelf water remains separated from slope water offshore by the shelf-break front, and only limited intrusions of offshore waters occur, such as entrainment of warm Gulf Stream rings and smaller eddies and mixing with slope water (e.g., Bisagni, 1983; Garvine et al., 1988; Walsh et al., 1988). Input of "new" nutrients from offshore waters is limited, leading to a predominant role of "regenerated" nutrients (i.e., inorganic nitrogen generated by oxidation of organic matter in shelf waters and sediments).

The VIS represents the northern end of the California Current System (CCS) on the Canadian West Coast (left-hand inset in Fig. 2). Northwesterly winds drive upwelling during summer while downwelling-favourable winds prevail in winter (Strub et al., 1987a,b). Shelf waves forced by winds 


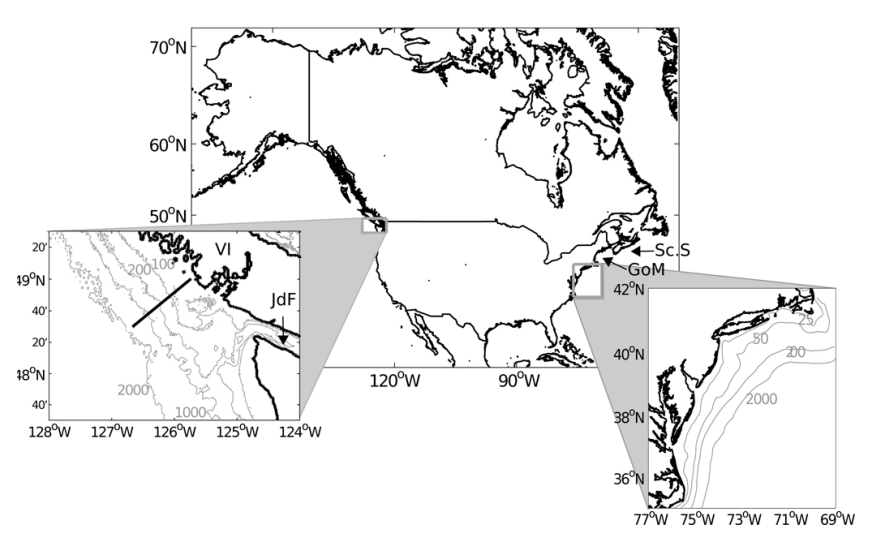

Fig. 2. Map of North America showing the Middle Atlantic Bight (MAB) in the east (right inset) and the Vancouver Island Shelf (VIS) in the west (left inset). The location of the transect represented by the VIS model is shown by the black line in the left inset, which also shows the 100, 200,1000, and $2000 \mathrm{~m}$ isobaths off the VIS. The inset on the right shows the $25,50,200$, and $2000 \mathrm{~m}$ isobaths from the MAB model bathymetry. Legends in the plot indicate key locations mentioned in the text: Vancouver Island (VI), Juan de Fuca Strait (JdF), Gulf of Maine (GoM), and Scotian Shelf (Sc.S).

further south in the CCS also drive upwelling on the VIS (Freeland and Denman, 1982). The Vancouver Island Coastal Current (VICC) flows northward near the coast, bringing nutrient-rich and relatively fresh waters from the Juan de Fuca Strait to the shelf (Thomson et al., 1989). Summer observations indicate the episodic presence over the continental shelf of upwelled waters from the California undercurrent as well as the influence of VICC waters on the VIS (Mackas et al., 1987). These two water sources supply nutrients to the shelf, fuelling new production and the growth of large diatom cells (Ianson et al., 2003; Harris et al., 2009).

"New" and "regenerated" nutrient production are typically equated with uptake of $\mathrm{NO}_{3}^{-}$and $\mathrm{NH}_{4}^{+}$, respectively (Dugdale and Goering, 1967). While in the open ocean the only significant source of $\mathrm{NO}_{3}^{-}$is from below the nutricline (i.e., $\mathrm{NO}_{3}^{-}$assimilation $=$new production), in the coastal ocean these concepts are less applicable. Allochthonous sources of $\mathrm{NH}_{4}^{+}$and the input of $\mathrm{NO}_{3}^{-}$from below the nutricline that resulted from previous nitrification of $\mathrm{NH}_{4}^{+}$prevent the association of $\mathrm{NO}_{3}^{-}$as an unambiguous "new" nutrient (e.g., Walsh et al., 1981; Falkowski et al., 1983).

\section{Model experiments and analysis}

The selected study areas represent coastal systems with different physical and biological dynamics. Both regions were modelled with the Regional Ocean Modelling System (ROMS, http://myroms.org, Haidvogel et al., 2008). The 3-D model for the MAB was developed and described by Fennel et al. (2006). It is nested within a model of the North American basin, which provides the necessary initial and boundary conditions. The MAB simulations were spun up for one year starting in January 2003 and then continued for the whole year 2004 (Fennel et al., 2008). For the VIS, a quasi-2-D model was used to represent a vertical section of a transect perpendicular to isobaths, with a uniform, small $(\sim 5 \mathrm{~km})$ alongshore dimension (Bianucci et al., 2011). Initial conditions were set horizontally uniform for all tracers and zero for velocities. Averages of observed summer deep ocean profiles were used for initialization, except for variables with no available observations. For these variables (phytoplankton, zooplankton, $\mathrm{NH}_{4}^{+}$, and detritus), small, vertically uniform constant values were used. Model experiments were 125-days long (first 50 days were spin-up), from 27 May to 29 September 1993, a year with upwelling conditions close to the climatological average (Bianucci et al., 2011). Since the VIS model was analyzed only from 16 July to 29 September to capture the upwelling season, we used the same time window of 75 days to analyze results from the MAB.

In addition to the different dimensions (2-D vs. 3-D), the models differ slightly in their biological components. While both nitrogen-based models include the same nutrients $\left(\mathrm{NO}_{3}^{-}, \mathrm{NH}_{4}^{+}\right.$, dissolved inorganic carbon), phytoplankton, zooplankton, and large detritus structure, the MAB model has a pool of small detritus while the VIS model includes dissolved organic matter (DOM) instead. The latter does not sink and has longer remineralization time scales than the small detritus pool in the MAB model. Despite this difference, the models have similar ecosystem dynamics and each model reproduces the biogeochemical characteristics of its region. Moreover, these models offer an opportunity to perform an inter-shelf comparison. Three different sediment parameterizations were implemented in the VIS model; here, we choose the same parameterization as in the MAB model (instantaneous remineralization of particulate organic matter reaching the seafloor, i.e., a reflective boundary). Given the quasi-2-D physical setup of the VIS model, the assumption of instantaneous remineralization of organic matter reaching the seafloor, and the prescribed sinking rate of detritus $\left(5 \mathrm{~m} \mathrm{~d}^{-1}\right)$, the shelf system reaches a quasi-steady state by the end of the 50-day spin-up period. Since both MAB and VIS models have sufficiently long spin-up times, the 75-day study period does capture the feedbacks between sediment denitrification and primary production in response to the varying forcing.

Both models consider coupled nitrification-denitrification in the sediments and assume the following stoichiometry for denitrification and nitrification:

$$
\begin{aligned}
& \mathrm{C}_{106} \mathrm{H}_{263} \mathrm{O}_{110} \mathrm{~N}_{16} \mathrm{P}+97.8 \mathrm{H}^{+}+84.8 \mathrm{NO}_{3}^{-} \rightarrow \\
& 106 \mathrm{CO}_{2}+42.4 \mathrm{~N}_{2}+16 \mathrm{NH}_{4}^{+}+\mathrm{PO}_{4}^{-3}+148.4 \mathrm{H}_{2} \mathrm{O} \\
& \mathrm{NH}_{4}^{+}+2 \mathrm{O}_{2} \rightarrow \mathrm{NO}_{3}^{-}+2 \mathrm{H}^{+}+\mathrm{H}_{2} \mathrm{O}
\end{aligned}
$$

From the oxidation of $1 \mathrm{~mol}$ of organic matter within the sediments (i.e., 16 mol-N, 106-mol-C), only a fraction $\psi$ is released as $\mathrm{NH}_{4}^{+}$back to the water column, while a fraction $1-\psi$ is lost as $\mathrm{N}_{2}$. The release of $\mathrm{NH}_{4}^{+}$from (and oxygen 
demand by) the sediments is based on an empirical relationship between coupled nitrification-denitrification and oxygen consumption in the sediments (Seitzinger and Giblin, 1996). A larger compilation of measurements gave essentially the same fit as Seitzinger and Giblin, indicating that bottom-water concentrations of $\mathrm{NO}_{3}^{-}$or $\mathrm{O}_{2}$ are not effective predictors of sediment denitrification in oxic environments (Fennel et al., 2009). Combining the Seitzinger and Giblin relationship and the assumption that organic matter reaching the sediments can only be remineralized aerobically or denitrified, Fennel et al. (2006) calculated that in the MAB model $86 \%$ of the oxidation of organic matter is aerobic and $14 \%$ occurs through coupled nitrification-denitrification. Further calculations led to a value of $\psi=4 / 16$ (see their Appendix A). Since the VIS model uses photosynthetic quotients (PQ, Laws, 1991) rather than Redfield's $\mathrm{O}_{2}$ :C ratio $\left(\mathrm{PQ}=1.1\right.$ vs. $\left.\mathrm{O}_{2}: \mathrm{C}=106: 106=1\right)$, the above calculations led to $85 \%$ aerobic remineralization, $15 \%$ denitrification, and $\psi=3 / 16$ in that model (Bianucci et al., 2011). The partition of benthic oxidation between aerobic and anaerobic pathways resulted in a different $\mathrm{O}_{2}: \mathrm{N}$ ratio for remineralization within the sediments compared with the water column. In the latter, $\mathrm{O}_{2}: \mathrm{N}$ ratios are 106:16 in the MAB and $117: 16$ on the VIS. In the sediments, oxygen is consumed following a $\mathrm{O}_{2}: \mathrm{N}$ ratio of $115: 16$ in the MAB and $125: 16$ on the VIS (Bianucci et al., 2011). If sediment denitrification is removed from the model, $100 \%$ of the organic matter reaching the seafloor is remineralized aerobically and benthic $\mathrm{O}_{2}$ : $\mathrm{N}$ ratios are identical to those of the water column.

The models also include water column nitrification, but do not consider nitrogen fixation. Inclusion of the latter process could have a major impact on the modelled ecosystem dynamics. However, denitrification is more important than $\mathrm{N}_{2}$ in the MAB, as shown by the predominantly negative observed $N^{*}$ values (Fennel, 2010). Moreover, in the MAB model, sediment denitrification leads to a nitrogen removal that exceeds estimates of $\mathrm{N}_{2}$ fixation by up to an order of magnitude (Fennel et al., 2006), although recent observations suggest that those estimates may have underestimated $\mathrm{N}_{2}$ fixation rates (Mulholland et al., 2012). To our knowledge, there is no evidence of significant $\mathrm{N}_{2}$ fixation in our study area over the VIS (Ianson and Allen, 2002). The usually cold waters and high uptake rates of either $\mathrm{NO}_{3}^{-}$or $\mathrm{NH}_{4}^{+}$in the region (Peña and Varela, 2007) would suggest unfavourable conditions for $\mathrm{N}_{2}$ fixation.

Oxygen dynamics are treated similarly in the MAB and VIS models. Oxygen is produced during photosynthesis with two different carbon to oxygen ratios, depending whether the nitrogen source is $\mathrm{NO}_{3}^{-}$or $\mathrm{NH}_{4}^{+}$. For these two ratios, the MAB model uses Redfield values of 138: 106 and 106: 106 (Redfield et al., 1963), while the VIS model uses photosynthetic quotients $\mathrm{PQn}=1.4$ and $\mathrm{PQa}=1.1$ (Bianucci et al., 2011). Oxygen is consumed at a fixed ratio during respiratory processes (Redfield ratio for the MAB and inverse of PQa for the VIS) and during nitrification. Air-sea oxygen exchange is parameterized using the gas transfer velocity by Wanninkhof (1992) and the oxygen saturation at surface by García and Gordon (1992), just as in the VIS model (Bianucci et al., 2011). Initial and boundary conditions for the MAB were derived from the NODC World Ocean Database as described in Fennel et al. (2006). For further details on the models, their equations, and their evaluation, refer to Fennel et al. (2006, 2008), Bianucci (2010), and Bianucci et al. (2011).

To evaluate the effect of sediment denitrification on bottom-water oxygen concentrations, we compared simulations in each region with and without this process. The change in near-bottom oxygen due to the presence of denitrification within the sediments was calculated as the relative difference of the oxygen fields in the near-bottom layer (i.e., deepest vertical level in the water column) between experiments:

$\Delta \mathrm{O}_{2}=100 \% \times\left(\mathrm{O}_{2}^{\mathrm{DNF}}-\mathrm{O}_{2}^{\mathrm{NoDNF}}\right) / \mathrm{O}_{2}^{\mathrm{NoDNF}}$,

where the superscripts DNF and NoDNF indicate simulations with and withouth sediment denitrification, respectively. In the case of primary production, we analyzed the absolute difference between experiments, since productivity offshore tends to be considerably lower than over the shelf, such that even small changes in production lead to large relative changes. Therefore, $\triangle \mathrm{PP}=\mathrm{PP}^{\mathrm{DNF}}-\mathrm{PP}^{\mathrm{NoDNF}}$, where $\mathrm{PP}$ is the vertically integrated primary production. Modelled primary production represents the combination of $\mathrm{NO}_{3}^{-}$and $\mathrm{NH}_{4}^{+}$assimilation.

Oxygen budgets for the bottom $10 \mathrm{~m}$ of the water column were used to analyze the processes that drive $\Delta \mathrm{O}_{2}$ over the shelf. For any given process (e.g., advection, remineralization in the sediments, etc.), the corresponding term of the budget was obtained by integrating the process over the bottom $10 \mathrm{~m}$ and averaging over time. These estimates were averaged horizontally over shelf regions shallower than $200 \mathrm{~m}$. The sum of all budget terms gives a spatial average of the total change in oxygen concentrations in the bottom $10 \mathrm{~m}$ for the period of study, in units of $\mathrm{mmol}_{-} \mathrm{O}_{2} \mathrm{~m}^{-2} \mathrm{~d}^{-1}$. An equivalent budget for dissolved inorganic nitrogen ( $\mathrm{DIN}=\mathrm{NO}_{3}^{-}+$ $\mathrm{NH}_{4}^{+}$), but for the whole water column rather than the bottom $10 \mathrm{~m}$, was calculated to emphasize the role of advection of nutrients compared with biological sources on each shelf system.

\section{Results}

Simulations with and without sediment denitrification (DNF and NoDNF experiments, respectively) allow us to evaluate the effect of this anaerobic process on near-bottom oxygen concentrations over both shelves. The mean $\Delta \mathrm{O}_{2}$ in the bottom layer of the models (average of 75 days) shows larger changes in the MAB than on the VIS (Fig. $3 a$ and b). On the VIS, the mean $\Delta \mathrm{O}_{2}$ only varies as a function of distance 

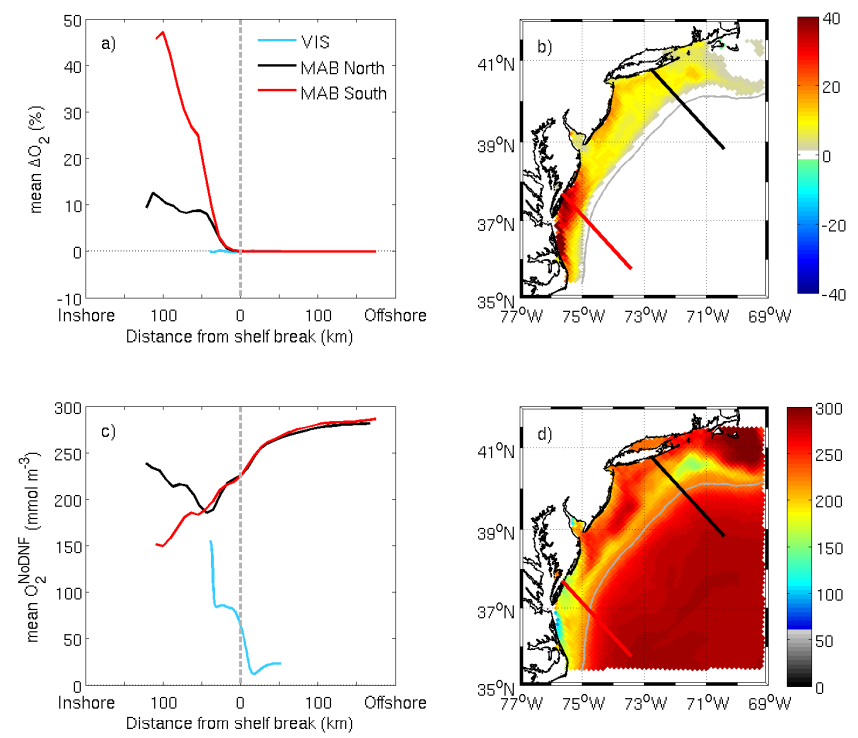

Fig. 3. (a, b) Change (in \%) of oxygen concentrations in the nearbottom layer of the two models due to the presence of sediment denitrification $\left(\Delta \mathrm{O}_{2}=100 \% \times\left(\mathrm{O}_{2}^{\mathrm{DNF}}-\mathrm{O}_{2}^{\mathrm{NoDNF}}\right) / \mathrm{O}_{2}^{\mathrm{NoDNF}}\right)$, averaged in the 75-day period of study: (a) Mean $\Delta \mathrm{O}_{2}$ as a function of distance from the shelf break in the VIS quasi-2-D model and in two transects from the MAB model; (b) Map of mean $\Delta \mathrm{O}_{2}$ for MAB domain, showing the two transects used in (a). (c, d) Averaged oxygen concentrations $\left(\mathrm{mmol} \mathrm{m}^{-3}\right)$ in the near-bottom layer of the two models for the experiments without sediment denitrification $\left(\mathrm{O}_{2}^{\mathrm{NoDNF}}\right)$ : (c) same as (a) for mean $\mathrm{O}_{2}^{\mathrm{NoDNF}}$; (d) same as (b) for $\mathrm{O}_{2}^{\mathrm{NoDNF}}$. The dashed vertical lines in (a) and (c) indicate the position of the shelf break ( $200 \mathrm{~m}$ isobath), shown as a grey contours in (b) and (d).

from the shelf break due to the 2-D (xz-plane) model domain (Fig. 3a, blue curve). Changes on the VIS are negligible, within $\pm 0.2 \%$. In the MAB, mean $\Delta \mathrm{O}_{2}$ was positive mostly everywhere (Fig. 3b), meaning that sediment denitrification resulted in an increase in near-bottom oxygen. To compare with the VIS changes, we selected two representative transects in the northern and southern MAB, near Long Island and Chesapeak Bay, respectively (black and red lines in Fig. 3b). $\Delta \mathrm{O}_{2}$ over the shelf in the northern transect is $\sim 10 \%$, while values in the southern transect exceed $45 \%$ (Fig. 3a, black and red curves). In the southern MAB, oxygen concentrations increased up to $182 \mathrm{mmol} \mathrm{m}^{-3}$ due to the presence of denitrification in the sediments. There, the NoDNF simulation reached hypoxic conditions $\left(\mathrm{O}_{2}<60 \mathrm{mmol} \mathrm{m}^{-3}\right)$ in areas shallower than $15 \mathrm{~m}$. Mean oxygen concentrations for the NoDNF experiments are shown for reference (Fig. $3 \mathrm{c}$ and d).

The loss of bioavailable nitrogen due to denitrification within the sediments decreased primary production significantly in the MAB (Fig. 4). While total production on the VIS barely changed between DNF and NoDNF experiments $\left(-0.01 \mathrm{gC} \mathrm{m}^{-2} \mathrm{~d}^{-1}<\Delta \mathrm{PP}<0\right.$, Fig. 4a, blue curve $)$, mean
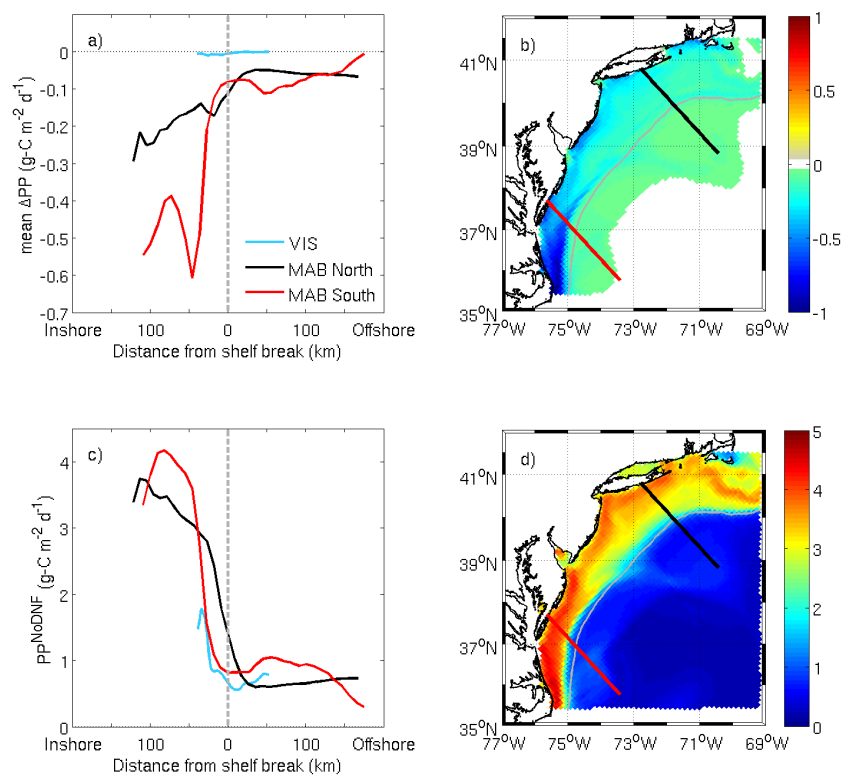

Fig. 4. (a, b) Change (in $\mathrm{gC} \mathrm{m}^{-2} \mathrm{~d}^{-1}$ ) of vertically integrated primary production due to the presence of sediment denitrification $\left(\triangle \mathrm{PP}=\mathrm{PP}^{\mathrm{DNF}}-\mathrm{PP}^{\mathrm{NoDNF}}\right)$, averaged in the 75-day period of study. (a) Mean $\triangle \mathrm{PP}$ as a function of distance from the shelf break in the VIS quasi-2-D model and in two transects from the MAB model. (b) Map of mean $\triangle \mathrm{PP}$ for MAB domain, showing the two transects used in (a). (c, d) Averaged vertically integrated primary production $\left(\mathrm{gC} \mathrm{m}^{-2} \mathrm{~d}^{-1}\right)$ in the two models for the experiments without sediment denitrification $\left(\mathrm{PP}^{\mathrm{NoDNF}}\right)$ : (c) same as (a) for mean $\mathrm{PP}^{\mathrm{NoDNF}}$; (d) same as (b) for $\mathrm{PP}^{\mathrm{NoDNF}}$. The dashed vertical lines in (a) and (c) indicate the position of the shelf break $(200 \mathrm{~m}$ isobath), shown as a grey contours in (b) and (d).

$\triangle \mathrm{PP}$ over the MAB is $-0.15 \mathrm{gC} \mathrm{m}^{-2} \mathrm{~d}^{-1}$ with minima of $-1 \mathrm{gC} \mathrm{m}^{-2} \mathrm{~d}^{-1}$ near Cape Hatteras (Fig. 4b). The representative MAB transects show larger $\triangle \mathrm{PP}$ than the VIS, both offshore and inshore of the shelf break (Fig. 4a). As waters leave the shelf at Cape Hatteras, flowing along the northern edge of the Gulf Stream (Ford et al., 1952), they transport shelf nutrients offshore. In the DNF simulation, the concentration of bioavailable nitrogen transported offshore was lower than in the NoDNF experiment, leading to the observed decrease of primary production adjacent to the shelf break. $\mathrm{NO}_{3}^{-}$assimilation represents $\sim 42 \%$ of the primary production in the VIS model compared with $\sim 25 \%$ in the MAB model.

Oxygen concentrations in bottom waters can change due to both physical and biological processes (Fig. 5). Vertical mixing tends to increase oxygen in the bottom, since upper layers usually have higher oxygen concentrations. However, advection can either increase or decrease oxygen over the shelf, depending on the direction of the currents and the horizontal oxygen gradients. All biological processes in the bottom layers of the water column (sediment and water column remineralization and nitrification) consume oxygen. In the 

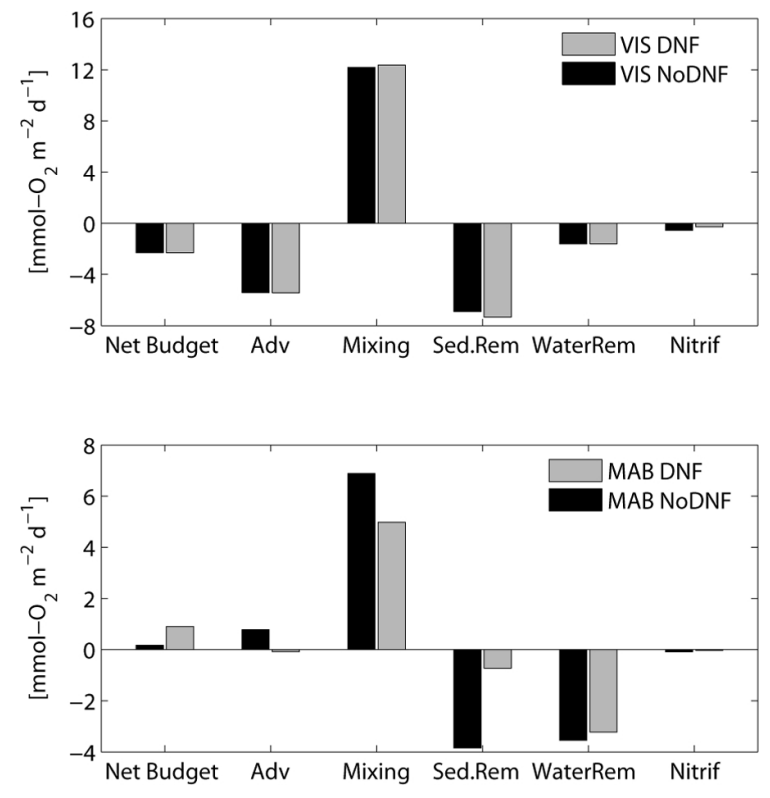

Fig. 5. Contributions to the $\mathrm{O}_{2}$ budget for the bottom $10 \mathrm{~m}$ of the water column of the modelled shelves (depth $\leq 200 \mathrm{~m}$ ), averaged over the 75 days of the analysis period: (top) VIS and (bottom) MAB. Experiments with and without denitrification in the sediments are shown as grey and black bars, respectively. The bottom axis reads: net budget (sum all of budget terms), advection (horizontal plus vertical), vertical mixing, sediment remineralization, remineralization of organic matter in the water column and nitrification in the water column. Positive fluxes are into the near-bottom layer.

$\mathrm{MAB}$, bottom oxygen increases during the 75 days of analysis in both simulations (positive "net budget" columns in Fig. 5), mainly due to the effect of vertical mixing. In contrast, both VIS experiments lost oxygen through onshore advection of low-oxygen waters and biological consumption. Furthermore, the relative importance of the different biological processes varied between study areas. On the VIS, sediment remineralization dominated the biological consumption of oxygen. However, sediment and water-column remineralization were similar in the MAB in the NoDNF experiment, while water-column remineralization was the largest oxygen sink in the DNF simulation.

The comparison of the oxygen budgets between the DNF and NoDNF experiments shows which processes led to the different magnitudes of mean $\Delta \mathrm{O}_{2}$ (Fig. 5). On the VIS, oxygen consumption by the sediments increased slightly in the DNF simulation with respect to the NoDNF experiment (Fig. 5a, grey and black bars, respectively), corresponding to Process 3 mentioned in Sect. 1 (extra oxygen consumption from coupled nitrification-denitrification). Moreover, oxygen consumption by nitrification decreased in the DNF case due to less available $\mathrm{NH}_{4}^{+}$in the water column (Process 2 from Sect. 1). As these changes are small and balance each other, variations in oxygen are negligible on this shelf (Fig. 3a, blue curve). However, in the MAB oxygen consumption by the sediments decreased sharply when denitrification was enabled (Fig. 5b, grey bars), following Process 1 (less sediment mass to be remineralized due to diminished primary production). This effect resulted in the higher oxygen concentrations and positive $\Delta \mathrm{O}_{2}$ in the bottom layers of the MAB model (Fig. 3b). Changes in the remaining biological processes (water-column remineralization, nitrification) in the DNF simulation contributed to a lesser extent to the decrease in oxygen consumption. Physical processes (advection, vertical mixing) re-adjusted themselves to the new oxygen gradients in the DNF simulation, compensating only partially for the smaller sinks of oxygen.

\section{Discussion and conclusions}

The role of denitrification within the sediments has been examined previously with respect to air-sea $\mathrm{CO}_{2}$ fluxes and carbon storage in the coastal ocean (Fennel et al., 2008; Thomas et al., 2009). Here, we investigated the effect of this anaerobic process on the oxygen concentrations of bottom waters and found different behaviour in our two study regions. The loss of bioavailable nitrogen through sediment denitrification significantly decreased primary production in the MAB, such that less organic matter reached the seafloor in the DNF simulation compared with the NoDNF experiment. Therefore, the DNF simulation shows a decrease in sediment remineralization and consequent decrease of sediment oxygen consumption. This diminished consumption leads to higher oxygen concentrations in the bottom layer and positive $\Delta \mathrm{O}_{2}$ (Fig. 3b). Compared with this strong effect in bottom oxygen concentrations, other processes affected by the presence of sediment denitrification (e.g., decreased water-column nitrification and higher $\mathrm{O}_{2}: \mathrm{N}$ ratios for sediment remineralization) are negligible. However, sediment denitrification barely affects primary production on the VIS. The small changes in sediment remineralization and nitrification balance each other and result in bottom $\Delta \mathrm{O}_{2} \sim 0$ (Fig. 3a, blue line).

These results suggest that the effect of sediment denitrification on bottom oxygen concentrations depends on the effect of this anaerobic process on primary production. If regenerated or recycled nutrients support most of the primary production, an alteration of the amount of biovailable nitrogen produced by the sediments can affect primary production over the shelf. In contrast, if nutrients from external sources (e.g., upwelled from the deep ocean) largely sustain phytoplankton growth, then a loss of recyled nitrogen from denitrification in the sediments does not strongly affect primary production. The dissolved inorganic nitrogen budget in our models shows that advection represents a large source of nutrients on the VIS, while it is not significant in the MAB (Fig. 6). Therefore, the VIS results are rather insensitive to denitrification, since external sources provide the required nutrients for primary production. 

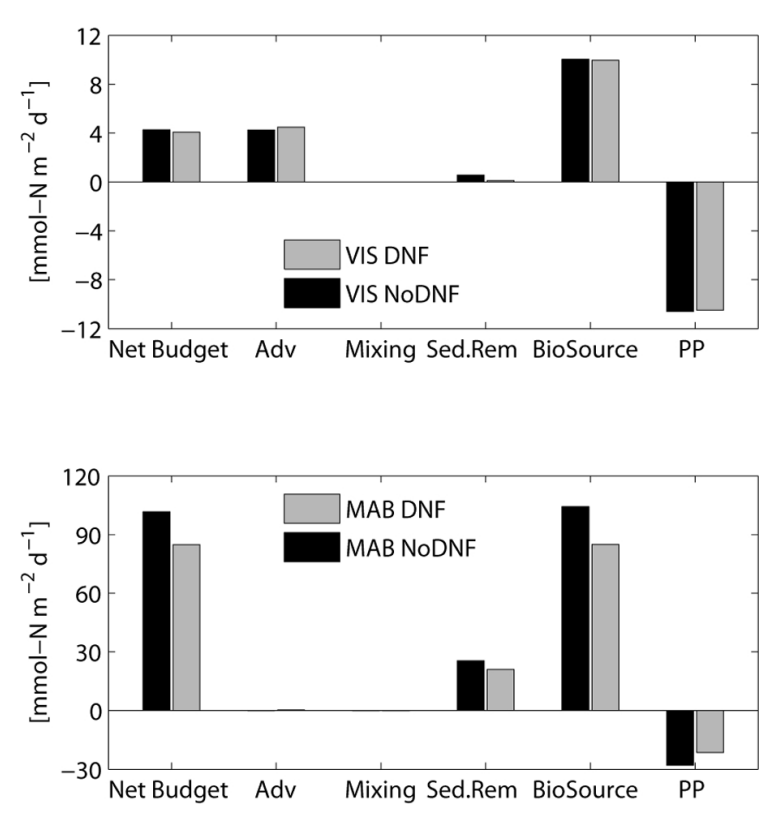

Fig. 6. Contributions to the DIN budget for the whole water column of the modelled shelves (depth $\leq 200 \mathrm{~m}$ ), averaged over the 75 days of the analysis period: (top) VIS and (bottom) MAB. Experiments with and without denitrification in the sediments are shown as grey and black bars, respectively. The bottom axis reads: net budget (sum all of budget terms), advection (horizontal plus vertical), vertical mixing, sediment remineralization, biological sources of DIN in the water column (remineralization of organic matter and zooplankton respiration) and primary production. Positive fluxes represent a gain of DIN by the shelf waters.

Waters in the MAB have spent a long time over the continental shelf off northeastern North America, since the coastal current system starts in the Labrador Sea (Chapman and Beardsley, 1989). The strong signal of sediment denitrification found in these waters provides evidence of the long residence time and the importance of nutrient regeneration on the shelf (Fennel, 2010). Observations indicate that recycled nutrients support high productivity in the MAB (Falkowski et al., 1988). In our model results, $\mathrm{NH}_{4}^{+}$assimilation represented $\sim 75 \%$ of production, which agrees with previous observational studies (50-80\% in the mixed layer, Harrison et al., 1983). Although the latter study only considered regenerated production in the mixed layer (mainly fueled by locally regenerated $\mathrm{NH}_{4}^{+}$), their values represent a lower limit for the regenerated production as calculated in our study (i.e., integrated over the whole water column, where the $\mathrm{NH}_{4}^{+}$consumed can be produced by the recycling of organic matter in deeper waters and/or the sediments). Both model and observations point towards the importance of regenerated nutrients in the MAB. Furthermore, $\mathrm{NO}_{3}^{-}$assimilation in this region cannot be thought of as "new" production supported from external sources of $\mathrm{NO}_{3}^{-}$. The long residence time of waters in the MAB (> 100 days, Mountain, 1991) on the shelves of the coastal current system (likely $>1 \mathrm{yr}$ ) allows for nitrification to transform regenerated $\mathrm{NH}_{4}^{+}$into $\mathrm{NO}_{3}^{-}$. Moreover, as mentioned in Sect. 1, the input of $\mathrm{NO}_{3}^{-}$from offshore waters in the MAB is limited. If the sediments were to release part of the $\mathrm{NO}_{3}^{-}$produced by nitrification to the water column (observed, e.g., by Middelburg and Soetaert, 2005), it would also complicate the idea of "new" production. However, on the VIS external sources of nutrients significantly contribute to primary production, such as the nutrient-rich VICC and wind-driven summer upwelling (e.g., Whitney et al., 2005; Hickey and Banas, 2008).

Intercomparison studies are fundamental to understanding the heterogeneous global coastal ocean. Ideally, the comparison of modelling experiments for different coastal regions would be done with physical models that follow the same setup and have identical biological models. These conditions are extremely hard to meet, since regional models are usually developed to study questions specific to a particular geographical location. The models used in this study are based on the same circulation model (ROMS), although in different physical configurations (quasi-2-D vs. 3-D). Their biological components differ only slightly in the modelling of two detritus pools (MAB) vs. a large detritus and a dissolved organic matter pool (VIS). Both models adequately reproduce the main physical (e.g., temperature, salinity) and biological (e.g., chlorophyll, $\mathrm{NO}_{3}^{-}$) characteristics of the two regions (see Fennel et al., 2006, 2008; Bianucci et al., 2011), allowing us to carry out this intercomparison. Our conclusions about the role of regenerated vs. new nutrients in each region are consistent with previous studies (e.g., Harrison et al., 1983; Falkowski et al., 1988; Ianson et al., 2003; Hickey and Banas, 2008).

The biological models used here assumed coupled nitrification-denitrification in the sediments (i.e., nitrification of $\mathrm{NH}_{4}^{+}$provides all the $\mathrm{NO}_{3}^{-}$for denitrification), so the sediments do not exchange $\mathrm{NO}_{3}^{-}$with the water column (Fennel et al., 2006; Bianucci et al., 2011). This assumption affects the results, since direct denitrification would create an additional sink of bioavailable nitrogen and may further alter the oxygen cycle. In particular, direct denitrification would strengthen the feedback between benthic denitrification and oxygen concentrations in bottom waters, by furthering limiting primary production and the flux of organic matter to the sediments. We are confident that this assumption is adequate for the MAB, where estimates from a long-term ecosystem observatory site (LEO-15) showed that coupled nitrification-denitrification supported $91-100 \%$ of total sediment denitrification (Laursen and Seitzinger, 2002). Observations in other nearby regions also indicate the predominance of this type of sediment denitrification, e.g., in Long Island Sound (Mackin and Swider, 1989) and the South Atlantic Bight (Hopkinson et al., 1991). No estimates of sediment denitrification are available for the VIS area. On the Washington shelf, just south of the study region, coupled nitrification-denitrification represents about $60 \%$ of 
total sediment denitrification (Devol, 1991), suggesting that direct denitrification may be significant on the VIS. However, advection of DIN to the whole VIS region represents a large source of inorganic nitrogen (Fig. 6). Therefore, given the external sources of new nutrients to the VIS (i.e., from wind-driven upwelling and the $\mathrm{NO}_{3}^{-}$rich VICC), direct denitrification is unlikely to strongly affect primary production and oxygen concentrations.

A relevant characteristic shared by our two study regions is that both are normoxic shelves, i.e., oxygen concentrations tend to be above the hypoxic threshold. Non-zero bottom water oxygen concentrations are required for coupled nitrification-denitrification to occur in the sediments (e.g., Kemp et al., 1990), since nitrification is an aerobic process. Moreover, the parameterization used in our models relies on the observed correlation between denitrification and sediment oxygen consumption (Seitzinger and Giblin, 1996), and is recommended only for oxic environments (Fennel et al., 2009). For instance, this parameterization does not consider that hypoxic bottom waters decrease coupled nitrificationdenitrification rates in the sediments (Kemp et al., 1990, 2009). Our parameterization also neglects other processes that can be important in low oxygen environments, such as dissimilatory nitrate reduction to ammonium or DNRA (Bohlen et al., 2011). Furthermore, hypoxic conditions can affect nutrient cycling within the sediments in indirect ways, e.g., by reducing benthic macrofauna bio-irrigation and bioturbation (Kemp et al., 2009; Middelburg and Levin, 2009).

The motivation for this work was to improve the understanding of oxygen dynamics by assessing the role of denitrification within the sediments on bottom-water oxygen concentrations. Our results indicate that sediment denitrification can impact oxygen concentrations on shelf regions where recycled nutrients support most of phytoplankton growth. In these regions, sediment denitrification should be considered as a factor influencing oxygen dynamics, since its effects are large enough to help maintain concentrations above the hypoxic threshold.

Acknowledgements. We thank Andrew Dale and two anonymous reviewers for their constructive comments, which helped improve the manuscript. L. B. acknowledges partial support from the Ocean Tracking Network. K. F. and K. D. acknowledge funding from their NSERC Discovery Grants.

Edited by: J. Middelburg

\section{References}

Bianucci, L.: Carbon, oxygen, and nitrogen cycles on the Vancouver Island shelf, Ph.D. thesis, University of Victoria, 2010.

Bianucci, L., Denman, K. L., and Ianson, D.: Low oxygen and high inorganic carbon on the Vancouver Island Shelf, J. Geophys. Res., 116, C07011, doi:10.1029/2010JC006720, 2011.
Bisagni, J. J.: Lagrangian Current Measurements within the Eastern Margin of a Warm-Core Gulf Stream Ring, J. Phys. Oceanogr., 13, 709-715, 1983.

Bohlen, L., Dale, A., Sommer, S., Mosch, T., Hensen, C., Noffke, A., Scholz, F., and Wallmann, K.: Benthic nitrogen cycling traversing the Peruvian oxygen minimum zone, Geochim. Cosmochim. Acta, 75, 6094-6111, doi:10.1016/j.gca.2011.08.010, 2011.

Chapman, D. C. and Beardsley, R. C.: On the Origin of Shelf Water in the Middle Atlantic Bight, J. Phys. Oceanogr., 19, 384-391, 1989.

Devol, A. H.: Direct measurement of nitrogen gas fluxes from continental shelf sediments, Nature, 349, 319-321, doi:10.1038/349319a0, 1991.

Dugdale, R. C. and Goering, J. J.: Uptake of new and regenerated forms of nitrogen in primary productivity, Limnol. Oceanogr., 12, 196-206, 1967.

Falkowski, P., Vidal, J., Hopkins, T., Rowe, G., Whitledge, T., and Harrison, W.: Summer nutrient dynamics in the Middle Atlantic Bight: primary production and utilization of phytoplankton carbon, J. Plankton Res., 5, 515-537, doi:10.1093/plankt/5.4.515, 1983.

Falkowski, P. G., Flagg, C. N., Rowe, G. T., Smith, S. L., Whitledge, T. E., and Wirick, C. D.: The fate of a spring phytoplankton bloom: export or oxidation?, Cont. Shelf Res., 8, 457-484, doi:10.1016/0278-4343(88)90064-7, 1988.

Fennel, K.: The role of continental shelves in nitrogen and carbon cycling: Northwestern North Atlantic case study, Ocean Sci., 6, 539-548, doi:10.5194/os-6-539-2010, 2010.

Fennel, K., Wilkin, J., Levin, J., Moisan, J., O’Reilly, J., and Haidvogel, D.: Nitrogen cycling in the Middle Atlantic Bight: results from a three-dimensional model and implications for the North Atlantic nitrogen budget, Global Biogeochem. Cy., 20, GB3007, doi:10.1029/2005GB002456, 2006.

Fennel, K., Wilkin, J., Previdi, M., and Najjar, R.: Denitrification effects on air-sea $\mathrm{CO}_{2}$ flux in the coastal ocean: Simulations for the northwest North Atlantic, Geophys. Res. Lett., 35, L24608, doi:10.1029/2008GL036147, 2008.

Fennel, K., Brady, D., DiToro, D., Fulweiler, R., Gardner, W., Giblin, A., McCarthy, M., Rao, A., Seitzinger, S., ThouvenotKorppoo, M., and Tobias, C.: Modeling denitrification in aquatic sediments, Biogeochem., 93, 159-178, doi:10.1007/s10533-0089270-z, 2009.

Ford, W., Longard, J., and Banks, R.: On the nature, occurrence and origin of cold low salinity water along the edge of the Gulf Stream, J. Mar. Res., 11, 281-293, 1952.

Freeland, H. and Denman, K.: A topographically controlled upwelling center off southern Vancouver Island, J. Mar. Res., 40, 1069-1093, 1982.

García, H. E. and Gordon, L. I.: Oxygen Solubility in Seawater: Better Fitting Equations, Limnol. Oceanogr., 37, 1307-1312, 1992.

Garvine, R. W., Wong, K.-C., Gawarkiewicz, G. G., McCarthy, R. K., Houghton, R. W., and Aikman, F., I.: The morphology of shelfbreak eddies, J. Geophys. Res., 93, 15593-15607, doi:10.1029/JC093iC12p15593, 1988.

Haidvogel, D., Arango, H., Budgell, W., Cornuelle, B., Curchitser, E., Lorenzo, E. D., Fennel, K., Geyer, W., Hermann, A., Lanerolle, L., Levin, J., McWilliams, J., Miller, A., Moore, A., Powell, T., Shchepetkin, A., Sherwood, C., Signell, R., Warner, 
J., and Wilkin, J.: Ocean forecasting in terrain-following coordinates: Formulation and skill assessment of the Regional Ocean Modeling System, J. Comput. Phys., 227, 3595-3624, doi:10.1016/j.jcp.2007.06.016, 2008.

Harris, S. L., Varela, D. E., Whitney, F. W., and Harrison, P. J.: Nutrient and phytoplankton dynamics off the west coast of Vancouver Island during the 1997/98 ENSO event, Deep-Sea Res. II, 56, 2487-2502, doi:10.1016/j.dsr2.2009.02.009, 2009.

Harrison, W., Douglas, D., Falkowski, P., Rowe, G., and Vidal, J.: Summer nutrient dynamics of the Middle Atlantic Bight: nitrogen uptake and regeneration, J. Plankton Res., 5, 539-556, doi:10.1093/plankt/5.4.539, 1983.

Hickey, B. M. and Banas, N. S.: Why is the Northern end of the California Current System so productive?, Oceanography, 21, 91107, 2008.

Hopkinson, C. S., J., Fallon, R. D., Jansson, B.-O., and Schubauer, J. P.: Community metabolism and nutrient cycling at Gray's Reef, a hard bottom habitat in the Georgia Bight, Mar Ecol. Prog. Ser, 73, 105-120, 1991.

Ianson, D. and Allen, S. E.: A two-dimensional nitrogen and carbon flux model in a coastal upwelling region, Global Biogeochem. Cy., 16, 1011, doi:10.1029/2001GB001451, 2002.

Ianson, D., Allen, S. E., Harris, S. L., Orians, K. J., Varela, D. E., and Wong, C. S.: The inorganic carbon system in the coastal upwelling region west of Vancouver Island, Canada, Deep-Sea Res. I, 50, 1023-1042, doi:10.1016/S0967-0637(03)00114-6, 2003.

Jørgensen, B. B.: Mineralization of organic matter in the sea bed-the role of sulphate reduction, Nature, 296, 643-645, doi:10.1038/296643a0, 1982.

Kemp, W. M., Sampou, P., Caffrey, J., Mayer, M., Henriksen, K., and Boynton, W. R.: Ammonium Recycling Versus Denitrification in Chesapeake Bay Sediments, Limnol. Oceanogr., 35, 1545-1563, 1990.

Kemp, W. M., Testa, J. M., Conley, D. J., Gilbert, D., and Hagy, J. D.: Temporal responses of coastal hypoxia to nutrient loading and physical controls, Biogeosciences, 6, 2985-3008, doi:10.5194/bg-6-2985-2009, 2009.

Laursen, A. E. and Seitzinger, S. P.: The role of denitrification in nitrogen removal and carbon mineralization in Mid-Atlantic Bight sediments, Cont. Shelf Res., 22, 1397-1416, doi:10.1016/S02784343(02)00008-0, 2002.

Laws, E. A.: Photosynthetic quotients, new production and net community production in the open ocean, Deep-Sea Res. A, 38, 143167, doi:10.1016/0198-0149(91)90059-O, 1991.

Mackas, D. L., Denman, K. L., and Bennett, A. F.: Least Squares Multiple Tracer Analysis of Water Mass Composition, J. Geophys. Res., 92, 2907-2918, doi:10.1029/JC092iC03p02907, 1987.

Mackin, J. E. and Swider, K. T.: Organic matter decomposition pathways and oxygen consumption in coastal marine sediments, J. Mar. Res., 47, 681-716, doi:10.1357/002224089785076154, 1989.

Middelburg, J. J. and Levin, L. A.: Coastal hypoxia and sediment biogeochemistry, Biogeosciences, 6, 1273-1293, doi:10.5194/bg-6-1273-2009, 2009.

Middelburg, J. J. and Soetaert, K.: The role of sediments in shelf ecosystem dynamics, in: The sea: ideas and observations on progress in the study of the seas, edited by: Robinson, A. R., McCarthy, J., and Rothschild, B. J., vol. 13, chap. 11, 353-374,
Harvard University Press, 2005.

Mountain, D. G.: The volume of Shelf Water in the Middle Atlantic Bight: seasonal and interannual variability, 1977-1987, Cont. Shelf Res., 11, 251-267, doi:10.1016/0278-4343(91)90068-H, 1991.

Mulholland, M. R., Bernhardt, P. W., Blanco-Garcia, J. L., Mannino, A., Hyde, K., Mondragon, E., Turk, K., Moisander, P. H., and Zehr, J. P.: Rates of dinitrogen fixation and the abundance of diazotrophs in North American coastal waters between Cape Hatteras and Georges Bank, Limnol. Oceanogr., 57, 1067-1083, 2012.

Peña, M. A. and Varela, D. E.: Seasonal and interannual variability in phytoplankton and nutrient dynamics along Line $\mathrm{P}$ in the NE subarctic Pacific, Prog. Oceanogr., 75, 200-222, doi:10.1016/j.pocean.2007.08.009, 2007.

Peña, M. A., Katsev, S., Oguz, T., and Gilbert, D.: Modeling dissolved oxygen dynamics and hypoxia, Biogeosciences, 7, 933957, doi:10.5194/bg-7-933-2010, 2010.

Ramp, S. R., Schlitz, R. J., and Wright, W. R.: The Deep Flow through the Northeast Channel, Gulf of Maine, J. Phys. Oceanogr., 15, 1790-1808, 1985.

Redfield, A. C., Ketchum, B. H., and Richards, F. A.: The influence of organisms on the composition of seawater, in: The Sea: Ideas and Observations on Progress in the Study of the Seas, edited by: Hill, M. N., vol. 2. The Composition of Seawater, Wiley, New York, 26-77, 1963.

Reed, D., Slomp, C., and Gustafsson, B.: Sedimentary phosphorus dynamics and the evolution of bottom-water hypoxia: A coupled benthic-pelagic model of a coastal system, Limnol. Oceanogr., 56, 1075-1092, 2011.

Seitzinger, S.: Denitrification in freshwater and coastal marine ecosystems: Ecological and geochemical significance, Limnol. Oceanogr., 33, 702-724, 1988.

Seitzinger, S. and Giblin, A.: Estimating denitrification in North Atlantic continental shelf sediments, Biogeochem., 35, 235-260, doi:10.1007/BF02179829, 1996.

Smith, P. C.: The Mean and Seasonal Circulation off Southwest Nova Scotia, J. Phys. Oceanogr., 13, 1034-1054, 1983.

Soetaert, K. and Middelburg, J.: Modeling eutrophication and oligotrophication of shallow-water marine systems: the importance of sediments under stratified and well-mixed conditions, Hydrobiologia, 629, 239-254, doi:10.1007/s10750-009-9777-x, 2009.

Sørensen, J., Jørgensen, B. B., and Revsbech, N. P.: A comparison of oxygen, nitrate, and sulfate respiration in coastal marine sediments, Microbial Ecology, 5, 105-115, 1979.

Strub, P. T., Allen, J. S., Huyer, A., and Smith, R. L.: LargeScale Structure of the Spring Transition in the Coastal Ocean off Western North America, J. Geophys. Res., 92, 1527-1544, doi:10.1029/JC092iC02p01527, 1987a.

Strub, P. T., Allen, J. S., Huyer, A., Smith, R. L., and Beardsley, R. C.: Seasonal Cycles of Currents, Temperatures, Winds, and Sea Level Over the Northeast Pacific Continental Shelf: $35^{\circ} \mathrm{N}$ to $48^{\circ} \mathrm{N}$, J. Geophys. Res., 92, 1507-1526, doi:10.1029/JC092iC02p01507, 1987b.

Thomas, H., Schiettecatte, L.-S., Suykens, K., Koné, Y. J. M., Shadwick, E. H., Prowe, A. E. F., Bozec, Y., de Baar, H. J. W., and Borges, A. V.: Enhanced ocean carbon storage from anaerobic alkalinity generation in coastal sediments, Biogeosciences, 6, 267274, doi:10.5194/bg-6-267-2009, 2009. 
Thomson, R. E., Hickey, B. M., and LeBlond, P. H.: The Vancouver Island coastal current: fisheries barrier and conduit, in: Effects of Ocean Variability on Recruitment and an Evaluation of Parameters Used in Stock Assessment Models, edited by: McFarlane, G., Can. Spec. Publ. Fish. Aquat. Sci., 265-296, 1989.

Walsh, J. J., Rowe, G. T., Iverson, R. L., and McRoy, C. P.: Biological export of shelf carbon is a sink of the global $\mathrm{CO}_{2}$ cycle, Nature, 291, 196-201, 1981.

Walsh, J. J., Biscaye, P. E., and Csanady, G. T.: The 1983-1984 shelf edge exchange processes (SEEP)-I experiment: hypotheses and highlights, Cont. Shelf Res., 8, 435-456, doi:10.1016/02784343(88)90063-5, 1988.
Wanninkhof, R.: Relationship Between Wind Speed and Gas Exchange Over the Ocean, J. Geophys. Res., 97, 7373-7382, doi:10.1029/92JC00188, 1992.

Whitney, F., Crawford, W., and Harrison, P.: Physical processes that enhance nutrient transport and primary productivity in the coastal and open ocean of the subarctic NE Pacific, Deep-Sea Res. II, 52, 681-706, doi:10.1016/j.dsr2.2004.12.023, 2005. 